International Journal of Biological Sciences

ISSN 1449-2288 www.biolsci.org 2006 2:10-16

Research paper

C2006 Ivyspring International Publisher. All rights reserved

\title{
$N A D(H)$ recycling activity of an engineered bifunctional enzyme galactose dehydrogenase/lactate dehydrogenase
}

\author{
Virapong Prachayasittikul 1, Sarah Ljung 2, Chartchalerm Isarankura-Na-Ayudhya ${ }^{1}$, Leif Bülow ${ }^{2}$
}

1. Department of Clinical Microbiology, Faculty of Medical Technology, Mahidol University, Bangkok, Thailand.

2. Department of Pure and Applied Biochemistry, Center for Chemistry and Chemical Engineering, Lund University, Lund, Sweden.

Corresponding address: Assoc. Prof. Dr.Virapong Prachayasittikul, Department of Clinical Microbiology, Faculty of Medical Technology, Mahidol University, 2 Prannok Rd., Bangkok-Noi, Bangkok, Thailand 10700. Tel: 662-849-6318, Telefax: 662-849-6330, E-mail: mtvpr@mucc.mahidol.ac.th. Prof. Dr.Leif Bülow, Department of Pure and Applied Biochemistry, Center for Chemistry and Chemical Engineering, Lund University, P.O. Box 124 SE-221 00 Lund, Sweden. Tel: + 464622295 94, Telefax: + 464622246 11, E-mail: leif.bulow@tbiokem.lth.se

Received: 2005.12.14; Accepted: 2006.02.20; Published: 2006.03.01

A chimeric bifunctional enzyme composing of galactose dehydrogenase (galDH; from Pseudomonas fluorescens) and lactate dehydrogenase (LDH; from Bacillus stearothermophilus) was successfully constructed. The chimeric galDH/LDH possessed dual characteristics of both galactose dehydrogenase and lactate dehydrogenase activities while exhibiting hexameric rearrangement with a molecular weight of approximately $400 \mathrm{kDa}$. In vitro observations showed that the chimeric enzyme was able to recycle NAD with a continuous production of lactate without any externally added NADH. Two fold higher recycling rate $(0.3 \mathrm{mM} / \mathrm{h})$ than that of the native enzyme was observed at $\mathrm{pH}$ values above 8.5. Proximity effects became especially pronounced during the recycling assay when diffusion hindrance was induced by polyethylene glycol. All these findings open up a high feasibility to apply the $\mathrm{NAD}(\mathrm{H})$ recycling system for metabolic engineering purposes e.g. as a model to gain a better understanding on the molecular proximity process and as the routes for synthesizing of numerous high-value-added compounds.

Key words: Chimeric bifunctional enzyme, NAD recycling, galactose dehydrogenase, lactate dehydrogenase, substrate channeling

\section{Introduction}

Vitalization and functioning achievements of cells are mainly based upon their metabolic activities which are frequently involved multiple enzymes in a compartmentalization of the subcellular structure arrangement. Channeling of substrate and proximity effects of enzymes in the metabolic compartment have been demonstrated and considered playing important role on metabolic regulation [1]. The channeling effect can be naturally occurred within a bifunctional/multifunctional enzyme or tightly associated multienzyme clusters or transient enzyme complexes. Tryptophan synthase from Neurospora crassa is an example of a single bifunctional enzyme channeling [2]. Meanwhile, in vitro, genetic engineering of novel bi- or multifunctional enzymes providing the putative channel in a close vicinity of two active sites has been reported [3]. These enzymes have further been applied as models for studying multienzyme reaction kinetics with particular focus on proximity and substrate channeling effects [4] both in vivo and in vitro [5]. However, proximity effect or channeling effect of coenzyme on the bifunctional enzyme still remains unexplored.
Coenzyme regeneration is essential in many enzymatic processes. Since the reduced forms of pyridine nucleotide cofactors are less stable and costly than the oxidized forms. Economically, to maximize the involving of cofactors, regeneration and recycling of the coenzyme within the enzyme reactor is often required. Engineering to generate the $\operatorname{NAD}(\mathrm{H})$ in a reaction has been performed by using both electrochemical [6] and photosensitized electron transfer [7]. However, the most common methods used are based on enzymatic regeneration [8, 9]. These include using a series of dehydrogenases e.g. alcohol dehydrogenase, formate dehydrogenase/hydrogenase and lipoamide dehydrogenase along with a low price sacrificial substrate $[10,11,12]$. In some circumstances, it is worth to note that encapsulation or immobilization of multienzyme cluster is needed to achieve the successful of sequential reactions $[13,14]$. Therefore, in this study, the use of artificial bifunctional enzyme has been extended to a recycling reaction as compared to the previous systems. A chimeric enzyme composing of the two oligomeric enzymes, lactate dehydrogenase (LDH) from Bacillus stearothermophilus [15] is fused in-frame with the galactose dehydrogenase (galDH) from Pseudomonas 
fluorescens [16] and applied for the production of lactate under continuous recycling of NADH using pyruvate and galactose as substrates. Possibility of proximity effect of the coenzyme of the bifunctional engineered enzyme will also be explored.

\section{Materials and methods}

\section{Chemicals and reagents}

Enzymes used for DNA manipulation and galDH were purchased from Boehringer Mannheim. A plasmid-DNA purification kit was from Promega. High molecular weight standard proteins for gel filtration were from Pharmacia. Acrylamide and bisacrylamide were obtained from Bio-Rad Laboratories. Standard proteins for polyacrylamide gel electrophoresis were purchased from Sigma. Peroxidase-conjugated swine anti-rabbit IgG was purchased from DAKO. All other reagents were of analytical grade.

\section{Bacterial strain and plasmids}

E. coli strain $F^{\prime} 11$ recA [(lac,pro) $\Delta$ thi, rifA, strA, recA/F'laclaZ- pro+] [17] was used as host. Plasmids pDZ10 [4] encoding galDH/ $\beta$-gal and pLDH41 [18] were utilized as sources for the galDH gene and ldh gene, respectively.

\section{Gel filtration of chimeric galDH/LDH}

The chimeric galDH/LDH was isolated from $E$. coli carrying pDU712 grown to late exponential phase in LB broth supplemented with $50 \mathrm{mg} / \mathrm{L}$ ampicillin. Cells were harvested by centrifugation at $10,000 \mathrm{~g}$ for 10 minutes and then resuspended in $0.1 \mathrm{M}$ sodium phosphate buffer, $\mathrm{pH} 6.0$ containing $0.2 \mathrm{M} \mathrm{NaCl}$ and 1 mM DTT (buffer A). The following steps were all carried out at $4^{\circ} \mathrm{C}$. After resuspension, cells were disrupted by sonic disintegration at output 5 with pulse on for $10 \times 15 \mathrm{~s}$ (Sonifer B-30, Branson Sonic Power). Crude extract was clarified by centrifugation at 20,000 g for 30 minutes. Ammonium sulfate was added slowly to the supernatant until $45 \%$ saturation was reached. The precipitate was pelleted by centrifugation at $20,000 \mathrm{~g}$ for 30 minutes, redissolved and dialyzed in buffer A for overnight. Any precipitate was removed by centrifugation at $40,000 \mathrm{~g}$ for 10 minutes. The supernatant was further subjected to gel filtration using Sephacryl S-400 Superfine (Pharmacia) column $(1.6 \times 100 \mathrm{~cm})$ equilibrated with buffer A. Fractions exhibiting both enzyme activities were collected. The molecular weight of the chimeric enzyme was determined using the standard protein markers: catalase $(232 \mathrm{kDa})$; ferritin $(440 \mathrm{kDa})$; aldolase $(580 \mathrm{kDa})$; and thyroglobulin $(669 \mathrm{kDa})$.

\section{Enzyme assays}

galDH activity was determined by using 16.6 $\mathrm{mM}$ galactose as substrate [19]. One unit of enzyme reduces $1 \mu \mathrm{mol}$ of galactose per minute at room temperature in $0.09 \mathrm{M}$ Tris- $\mathrm{HCl}, \mathrm{pH} 8.5$ containing 0.5 mM NAD. Assay of LDH activity was performed in 0.1 M MES buffer, pH 6.5 containing $0.2 \mathrm{mM}$ NADH and $30 \mathrm{mM}$ pyruvate. One unit of enzyme reduces 1 $\mu \mathrm{mol}$ of pyruvate per minute at room temperature.

The change in absorbance at $340 \mathrm{~nm}$ was followed spectrophotometrically in both assays. Protein concentrations were determined according to Bradford [20] using bovine serum albumin as standard. The $\mathrm{pH}$ profiles of $\mathrm{LDH}$ and galDH activities of the fusion and native enzymes were monitored in $0.1 \mathrm{M}$ Tris- $\mathrm{HCl}$ in the $\mathrm{pH}$ range of 7.0 to 10.5 and in $0.1 \mathrm{M}$ sodium phosphate buffer in the $\mathrm{pH}$ range of 5.0 to 7.0 , respectively.

\section{SDS-PAGE and Western blotting}

SDS-PAGE was performed on $8 \%$ polyacrylamide slab gels using Tris-glycine, $\mathrm{pH}$ 8.3, discontinuous buffer system as described by Laemmli [21]. The molecular weights of the chimeric enzyme subunits were determined by comparing the relative mobilities with those of the standard proteins: myosin (205 kDa); $\beta$-galactosidase (116 kDa); phosphorylase b (97 kDa); bovine serum albumin (66 kDa); ovalbumin $(45 \mathrm{kDa})$; and carbonic anhydrase $(29 \mathrm{kDa})$.

For Western blotting, the proteins were transferred to a Millipore Immobilon TMPVDF transfer membrane using a Semi-Dry Electroblotter A (JKA-Biotech). To generate antibodies against galDH, rabbits were immunized with galDH. The antiserum was treated with ammonium sulfate to precipitate the antibodies and the precipitate was then resolved in $0.02 \mathrm{M}$ Tris- $\mathrm{HCl}, \mathrm{pH} 7.5$ containing $0.5 \mathrm{M} \mathrm{NaCl}$. Western blots were developed using the rabbit antibacterial galDH as first antibody and peroxidaseconjugated swine anti-rabbit IgG (DAKO, Denmark) as second antibody. Hydrogen peroxide and 4chloro-1-naphtanol were used as substrates for peroxidase, according to instructions from supplier. Visualization of standard protein markers was performed using amido black staining.

\section{Stability measurements}

Each of the chimeric galDH/LDH obtained after gel filtration, native $\mathrm{LDH}$ and galDH was subjected to thermal denaturation at 50 and $60^{\circ} \mathrm{C}$ in $0.1 \mathrm{M}$ sodium phosphate buffer, $\mathrm{pH} 6.0$ containing $0.2 \mathrm{M} \mathrm{NaCl}$ and 1 mM DTT. Enzyme stability was also monitored in urea concentrations ranging from 1 to $7 \mathrm{M}$ using the same buffer.

\section{NADH recycling}

The chimeric galDH/LDH obtained after gel filtration was added to $0.1 \mathrm{M}$ Tris- $\mathrm{HCl}$ containing 0.5 $\mathrm{mM}$ NAD, $17 \mathrm{mM}$ galactose and $30 \mathrm{mM}$ pyruvate. The reactions were evaluated at $\mathrm{pH} 8.1, \mathrm{pH} 8.9$ and $\mathrm{pH} 9.6$ by withdrawing samples of the reaction mixture at various time intervals. The samples were firstly deproteinized in an equal volume of $0.6 \mathrm{M}$ perchloric acid and then neutralized with $0.3 \mathrm{M} \mathrm{KOH}$. The levels of lactate produced in these samples were assayed enzymatically as described by Noll [22]. The kinetic properties of the chimeric enzyme were tested and compared with those obtained from the native enzyme. Production of lactate was also assayed in 
recycling reactions containing various concentrations of polyethylene glycol 20,000 ranging between 0 and $20 \%$.

\section{Results}

\section{Construction of a chimeric gene encoding chimeric galDH/LDH}

Experiment was initiated by partially digested the plasmid pUCLDH with Bsm I. A chemically synthesized DNA fragment coding for a $B a m \mathrm{H}$ I restriction site along with 7 amino acids linker region was then inserted into the pUCLDH at the 5 '- end of the $l d h$ gene, generating the plasmid pUCLDHv. The pUCLDHv was subsequently digested with $S c a$ I and partially with BamH I. The ldh fragment from pUCLDHv was then fused in-frame with the galdh gene originating from pDZ10 previously digested with BamH I and Sca I. The plasmid pDU712 (Figure 1) was transformed and expressed in E. coli strain F'11.

Figure 1. A. Schematic illustration of plasmid pDU712 encoding an in-frame fusion between galDH and LDH. B. Nucleotide sequence of the linker region between the fused galDH and LDH.

A

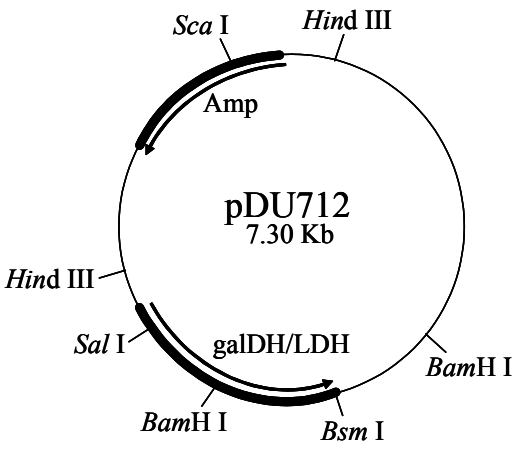

B

303304

GalDH- TAC GAT GGG GAT CCG GCA ATG AAA AAG -LDH BamH I

\section{Molecular size estimation of chimeric galDH/LDH}

The chimeric galDH/LDH was partially isolated by ammonium sulphate precipitation and gel filtration. The elution profiles from gel filtration showed that the chimeric enzyme possessed dual characteristics of both galDH and LDH activities as represented in Figure 2. The complete length of fusion protein eluted in one peak corresponded to a molecular weight of $400 \mathrm{kDa}$. Meanwhile, two additional peaks that could be recognized in the chromatogram demonstrated neither LDH nor galDH activity. The specific activities of the two enzyme moieties were in the range of $2-10 \mathrm{U} / \mathrm{mg}$. Interestingly, the specific LDH activity was 5-6 time higher than the galDH activity (Table 1).

In parallel, the molecular weight of the chimeric galDH/LDH was determined via SDS-PAGE followed by Western blotting. From the Western blot, the molecular size of the chimeric galDH/LDH subunit was approximately $69 \mathrm{kDa}$ (Figure 3; upper bands). Since the native galDH was a dimeric enzyme which has a molecular weight of $33 \mathrm{kDa}$ per monomer [4] while the native LDH existed mainly as a tetrameric form with a monomeric molecular weight of $35 \mathrm{kDa}$. Our finding was in a good agreement with the theoretical calculation $(68.5 \mathrm{kDa})$ of the complete length fusion protein. Taken together with the gel filtration experiments, these data supported the notion that the active form of galDH/LDH was present mainly as a hexameric form.

Table 1. Isolation of galDH/LDH from E. coli $\mathrm{F}^{\prime} 11$ carrying pDU712*

\begin{tabular}{|c|c|c|c|c|}
\hline Protein fraction & \multicolumn{2}{|c|}{ LDH } & \multicolumn{2}{c|}{ galDH } \\
\cline { 2 - 5 } & $\begin{array}{c}\text { Activity } \\
\text { (U) }\end{array}$ & $\begin{array}{c}\text { Specific } \\
\text { activity } \\
\text { (U/mg) }\end{array}$ & $\begin{array}{c}\text { Activity } \\
\text { (U) }\end{array}$ & $\begin{array}{c}\text { Specific } \\
\text { activity } \\
\text { (U/mg) }\end{array}$ \\
\hline Homogenate & 27.8 & 0.68 & 4.56 & 0.11 \\
\hline $\begin{array}{c}\text { Ammonium sulfate }(0- \\
\text { 45\%) precipitation }\end{array}$ & 20.0 & 2.45 & 3.95 & 0.48 \\
\hline Sephacryl S-400 & 20.0 & 6.54 & 3.25 & 1.04 \\
\hline
\end{tabular}

*Results are obtained from a $250 \mathrm{ml}$ bacterial culture grown to late exponential phase

Figure 2 Gel filtration of galDH/LDH. A Sephacryl S-400 Superfine column $(1.6 \times 100 \mathrm{~cm})$ equilibrated with $0.1 \mathrm{M}$ sodium phosphate buffer $\mathrm{pH} 6.0$ containing $0.2 \mathrm{M} \mathrm{NaCl}$ and $1 \mathrm{mM}$ DTT was used for the fractionation. Fraction volumes were $2.8 \mathrm{ml}$ and the flow rate was $0.14 \mathrm{ml} / \mathrm{min}$.

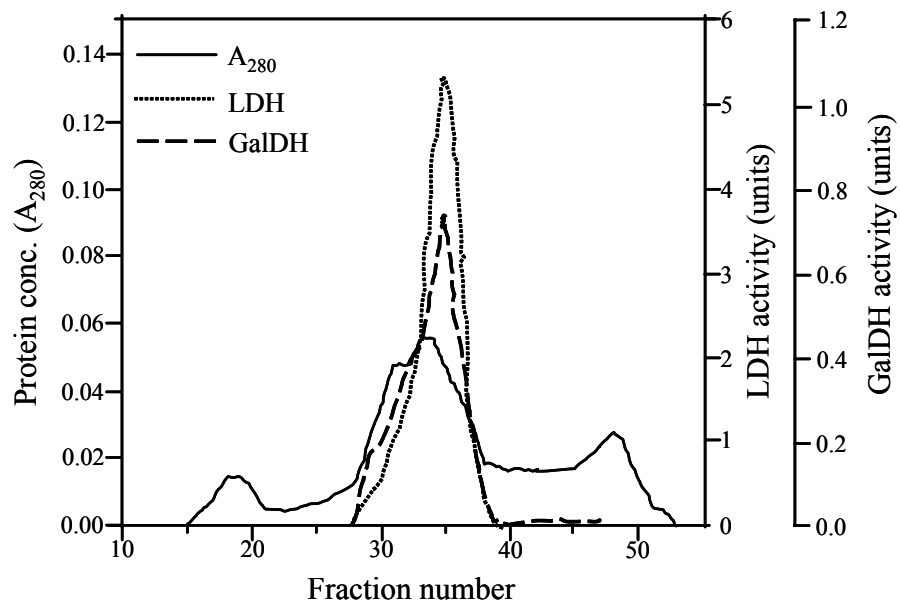

Thermal and urea stability of chimeric galDH/LDH

Stability against heat and urea denaturation of the chimeric galDH/LDH was tested. As shown in Figure $4 \mathrm{~A}$, it was obvious that the $\mathrm{LDH}$ portion of the chimeric galDH/LDH was more thermolabile than its native counterpart upon exposure to heat treatment at $60^{\circ} \mathrm{C}$. A markedly decrease of $\mathrm{LDH}$ activity up to $90 \%$ was observed within 30 minutes. By contrarily, the galDH part was more stable than the native enzyme since the remaining activity up to $90 \%$ could be detected at 90 minutes incubation time. At $50^{\circ} \mathrm{C}$, the denaturation profile of LDH was biphasic (Figure $4 \mathrm{~B})$. The LDH activity was rapidly reduced within 10 minutes and remained stable at approximately $60 \%$ of original activity. To evaluate whether the loss of 
activity was attributable to the decomposition into smaller oligomeric arrangements, the chimeric galDH/LDH was subjected to gel filtration after heat denaturation process (data not shown). From the chromatogram, it was concluded that the active chimeric enzyme still appeared in the hexameric form and no additional peaks was observed. Therefore, the loss of activity was most probably not due to decomposition of the hexameric structure but rather to internal polypeptide rearrangements.

Figure 3 Western blot of galDH/LDH. Samples of the fusion protein from gel filtration diluted 10- (lane II) and 100- (lane III) fold were separated on SDS-PAGE with crude extract from the host cells as reference (lane I). The gel was blotted and detected using rabbit anti-galactose dehydrogenase $\operatorname{IgG}$ and peroxidase conjugated swine anti-rabbit IgG.

\section{II III}

205000

116000

$97400-$

$66000-$

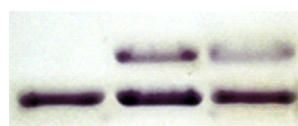

$45000-$

$29000-$

Figure 4 Heat stability of galDH/LDH compared with native enzymes. The enzymes were heated at $60^{\circ} \mathrm{C}(\mathrm{A})$ and $50^{\circ} \mathrm{C}(\mathrm{B})$ over time intervals as indicated and residual activities were determined. LDH activity of native LDH (•), LDH activity of chimeric galDH/LDH (०), galDH activity of native galDH (•) and galDH activity of chimeric galDH/LDH (口).

A

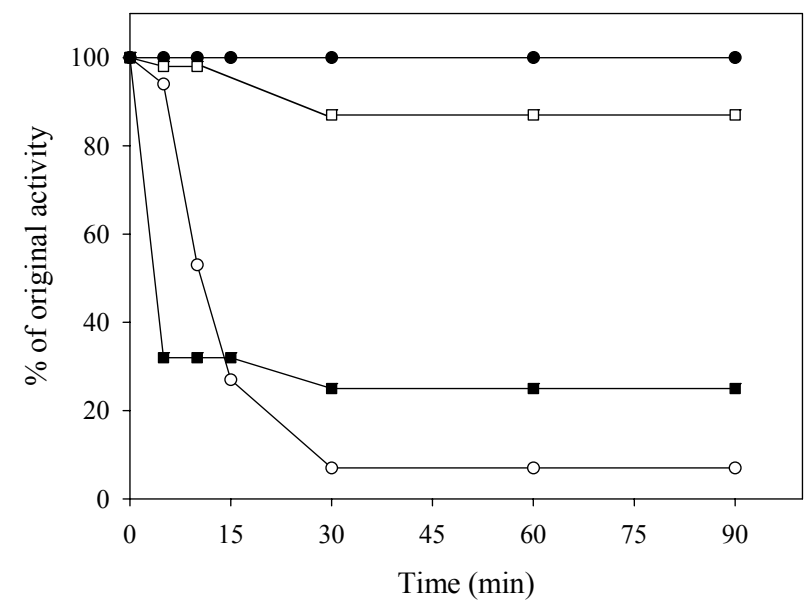

B

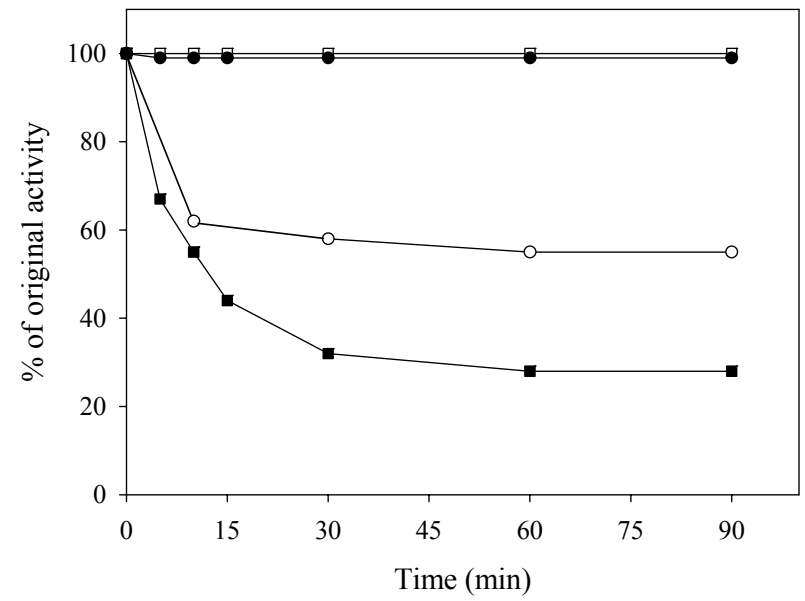




\section{Michaelis constants $(\mathrm{Km})$ and $\mathrm{pH}$ profiles of chimeric galDH/LDH}

Assay of the Michaelis constants $(\mathrm{Km})$ of the chimeric galDH/LDH was performed. The $\mathrm{Km}$ of $0.10 \mathrm{mM}$ for NADH (LDH activity) and $0.13 \mathrm{mM}$ for NAD (galDH activity) were observed. These values were not much different from those obtained from native LDH $(0.10 \mathrm{mM})$ and galDH $(0.15 \mathrm{mM})$.

The maximal activity of chimeric galDH/LDH at various $\mathrm{pHs}$ was investigated. The highest activities of LDH and galDH were found at $\mathrm{pH} 6.5$ and 10.5 as compared to 5.0 and 10.0 of the native LDH and native galDH, respectively. A similar shift in $\mathrm{pH}$ optima for galDH fused with $\beta$-galactosidase was previously observed by Ljungcrantz et al. [4].

\section{NAD recycling capability of chimeric galDH/LDH}

To test the NAD recycling capability of chimeric galDH/LDH, the optimum $\mathrm{pH}$ for $\mathrm{NAD}(\mathrm{H})$ was adjusted to give rise the enzyme activity ratio nearly close to one. The recycling reaction assays were performed at $\mathrm{pH} 8.1,8.9$ and 9.6 where the $\mathrm{LDH}$ and galDH activities were matched at $\mathrm{pH} 6.5$ and 8.5, respectively. The recycling rate was determined as the amount of lactate produced per hour. Although, the galDH/LDH gave approximately $30 \%$ lower recycling rates than those of the native at $\mathrm{pH} 8.1$ and 8.9. However, it was shown that at $\mathrm{pH} 9.6$ the rate was 2 fold greater than that of the native enzyme (Figure 5). Explanation on the disparity of cofactor regeneration between the native and chimeric enzyme could be drawn on the alteration of $\mathrm{pH}$ optima upon fusion. The native LDH retained only $5 \%$ of the maximum activity at $\mathrm{pH} 9.6$ while approximately $20 \% \mathrm{LDH}$ activity could be obtained in the case of galDH/LDH.

Figure 5 Recycling of $\mathrm{NAD}(\mathrm{H})$ at various $\mathrm{pHs}$. The $\mathrm{NAD}(\mathrm{H})$ recycling reaction was initiated by adding $30 \mathrm{mM}$ pyruvate, $17 \mathrm{mM}$ galactose and $0.5 \mathrm{mM}$ NAD at the $\mathrm{pH}$ values indicated. Samples were withdrawn and the amount of produced lactate was determined enzymatically.

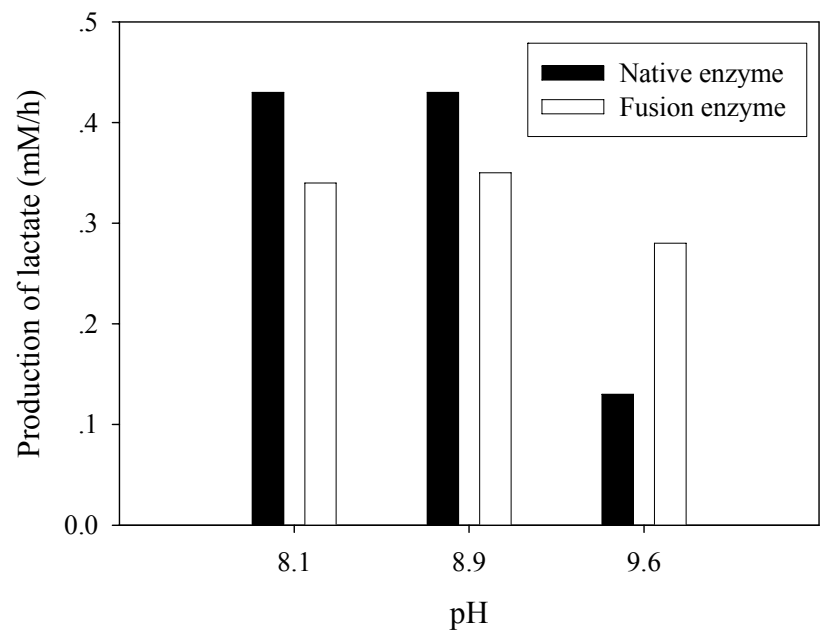

\section{Proximity effects on NAD recycling of chimeric galDH/LDH}

To mimic the intracellular milieu, proximity effect on the NAD recycling was further evaluated in reaction mixtures containing various concentrations of PEG 20,000. The $\mathrm{pH}$ chosen in this assay was 9.6 since all enzymatic activities were matched at this $\mathrm{pH}$ to ensure that the enzymatic activities of the fused and native systems were identical. Samples were withdrawn after 10 minutes and the production of lactate was assayed enzymatically. In the absence of PEG, a similar quantity of lactate was achieved in both systems (Figure 6). By contrarily, a markedly increase up to 5 fold in the production of lactate corresponding to the PEG concentration of $20 \%$ was observed in the case of chimeric galDH/LDH.

Figure 6 Recycling of $\mathrm{NAD}(\mathrm{H})$ at $\mathrm{pH} 9.6$ in reaction medium containing polyethylene glycol 20,000. The amount of produced lactate was estimated after 10 minutes of reaction. The activities of the chimeric enzyme and native enzymes were matched at $\mathrm{pH}$ 9.6. Open and filled circles represent native and chimeric enzymes, respectively.

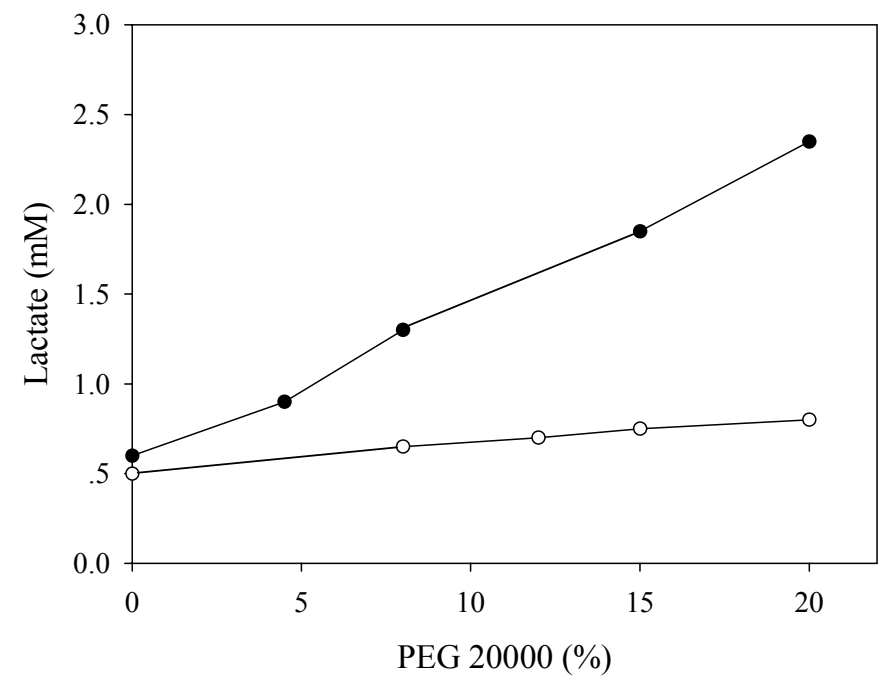

\section{Discussion}

\section{Simultaneous production of lactate through cofactor recycling of a bifunctional galDH/LDH}

Herein, a chimeric redox enzyme (galDH/LDH) possessing the ability to produce lactate under continuous recycling of $\mathrm{NAD}(\mathrm{H})$ has successfully been constructed. Simultaneous generation of lactate at $0.3 \mathrm{mM} / \mathrm{h}$ can be achieved at a high basidic condition ( $\mathrm{pH}$ 9.6). This rate is approximately 2 fold higher than that of the native enzyme (Figure 5). It is worth to state that the recycling of $\mathrm{NAD}(\mathrm{H})$ in this system does not show any immediate evidence for such physical channeling. Since the channeling may be dependent on physical transfer with the aid of ionic and hydrophobic interactions. Recent studies on the naturally occurring multienzyme dihydrofolate reductase/thymidylate synthase and 
on artificial bifunctional enzymes composed of enzymes in the citric acid cycle, e.g. malate dehydrogenase/citrate synthase, have shown evidences of electrostatic channeling, where the intermediate metabolite is transferred from one active site to the other via an electrostatic interaction on the surface of bifunctional enzyme [23, 24, 25]. In our case, when using a scavenger enzyme assay in vitro in which diaphorase is competing for the formed $\mathrm{NADH}$, no difference between the fusion enzyme and the matched native enzymes can hence be detected (data not shown). Meanwhile, proximity effects are clearly observed when diffusion hindrance in the form of PEG addition has been applied to the reaction (Figure 6). Such effect may be particularly useful when utilizing chimeric $N A D(H)$ recycling enzymes for metabolic engineering purposes. However, further work is required to understand whether the recycling occurs upon transiently gathering the two active sites into a close proximity to generate an enclosure that allows direct transmission of the intermediate and sterically prevents its leakage into the bulk phase. This has been believed to be involved in the channeling of NADH between dehydrogenases of opposite chiral specificity for the C-4 hydrogen of NADH [26, 27].

\section{Physical characteristics and molecular arrangements of chimeric galDH/LDH}

Based on our findings, no difference between the rate of reaction $(\mathrm{Km})$ mediated by the chimeric galDH/LDH and native enzymes has been found. This clearly indicates that only minor structural changes may have occurred in the native coenzyme binding sites. Since the Michaelis constants provide a general indication of possible distortion around the active sites upon fusion to the other proteins. Fusion of the two enzymes in some circumstances affects the three-dimensional structure of the oligomeric protein in such a way that the subunit interactions are partly perturbed or the active site might be sterically hindered.

Molecular conformation and new sets of intrapolypeptide interactions in the chimeric protein are likely to drive the obtained quaternary structure into perhaps more than one arrangement. The most physical stability of these structures will emerge as the dominant one after purification and constitute the fusion enzyme studied in vitro. The fusion of the structural genes of two oligomeric proteins can be expected to give rise to the formation of protein polymers in vivo. The hexameric complex formed in this study, therefore, does not constitute the native subunit arrangement neither for galDH (dimeric) nor for LDH (tetrameric). These non-native interactions have strikingly opposite effects on the two enzyme moieties compared with their native counterparts. The stability of the galDH part of the fusion protein has hence been substantially increased. Similar stabilization effects of galDH fusions have previously been reported by Ljungcrantz et al. [4] between $\beta$ - galactosidase and galDH and by Lindbladh et al. [5] between luciferase and galDH. The hexameric structure of the fusion protein apparently protects galDH from thermal and urea denaturation (Figure 4). However, the hexamer does not constitute an ideal arrangement for LDH, which precludes further purification of our hybrid. For instance, the LDH moiety rapidly lost its activity on ion exchange and affinity chromatography columns. To facilitate the handling of galDH/LDH it will be interesting to study if the folding pattern can be altered and given rise to other more stable three-dimensional arrangements. One approach can be co-expression with native subunits of one of the two fusion partners. Yet another approach will be to modify the design of the linker region in between the two enzyme moieties since it has been shown to have an impact on the stability and kinetics of fusion enzymes [28]. Moreover, previous studies on overexpression of oligomeric proteins together with chaperonins have resulted in elevated yields of correctly folded and assembled proteins [29]. Plasmid pDU712 has, therefore, been co-transformed with an expression plasmid encoding chaperonins GroES and GroEL [30], and the expressed proteins have been analyzed by gel exclusion chromatography. The oligomeric arrangement of enzymatic active protein complexes has been identical with expression of the fusion enzyme without chaperonins, a hexameric complex with the same characteristics as the original hexameric complex. However, the yield of correctly folded protein per litre cultivation has slightly been increased, approximately $10 \%$. Such findings indicate that the gene fusion technique provides a simple way to express and purify artificial proteins carrying more than one enzymatic function within a single protein body in which the applications can be found both in metabolic engineering and biochemical analyses [3, 31].

\section{Acknowledgements}

This project was supported by the Swedish Research Council for Engineering Sciences (TFR). We also wish to acknowledge Dr. Anthony A. Gatenby for the kind gift of plasmid pGroESL.

\section{Conflict of interest}

The authors have declared that no conflict of interest exists.

\section{References}

1. Huang $X$, Holden HM, Raushel FM. Channeling of substrates and intermediates in enzyme-catalyzed reactions. Annu Rev Biochem 2001;70:149-180.

2. Matchett WH, DeMoss JA. The subunit structure of tryptophan synthase from Neurospora crassa. J Biol Chem 1975;250(8):2941-2946.

3. Bülow L. Preparation of artificial bifunctional enzymes by gene fusion. Biochem Soc Symp 1990;57:123-133.

4. Ljungcrantz P, Carlsson H, Mansson MO, Buckel P, Mosbach $\mathrm{K}$, Bülow L. Construction of an artificial bifunctional enzyme, beta-galactosidase/galactose dehydrogenase, exhibiting 
efficient galactose channeling. Biochemistry 1989;28(22):87868792.

5. Lindbladh C, Persson M, Bülow L, Mosbach K. Characterization of a recombinant bifunctional enzyme, galactose dehydrogenase/bacterial luciferase, displaying an improved bioluminescence in a three-enzyme system. Eur J Biochem 1992;204(1):241-247.

6. Delecouls-Servat K, Bergel A, Basseguy R. Membrane electrochemical reactors (MER) for NADH regeneration in HLADH-catalysed synthesis: comparison of effectiveness. Bioprocess Biosyst Eng 2004;26(4):205-215.

7. Julliard M, Petit JL, Ritz P. Regeneration of NAD+ cofactor by photosensitized electron transfer in an immobilized alcohol dehydrogenase system. Biotech Bioeng 1985;28:1774-1779.

8. Mansson MO, Larsson PO, Mosbach K. Recycling by a second enzyme of NAD covalently bound to alcohol dehydrogenase. FEBS Lett 1979;98(2):309-313.

9. Ikemi M, Ishimatsu $\mathrm{Y}$. The membrane bioreactor with coenzyme recycling system. J Biotechnol 1990;14(2):211-220.

10. Larsson KM, Adlercreutz P, Mattiasson B. Activity and stability of horse-liver alcohol dehydrogenase in sodium dioctylsulfosuccinate/cyclohexane reverse micelles. Eur J Biochem 1987;166(1):157-161.

11. Orlich B, Schomaecker R. Enzymatic reduction of a less watersoluble ketone in reverse micelles with NADH regeneration. Biotechnol Bioeng 1999;65(3):357-362.

12. Hilhost R, Laane C, Veeger C. Enzymatic conversion of apolar compounds in organic media using an NADH-regenerating system and dihydrogen as reductant. FEBS Lett 1983;159:225228.

13. Ichinose H, Kamiya N, Goto M. Enzymatic redox cofactor regeneration in organic media: functionalization and application of glycerol dehydrogenase and soluble transhydrogenase in reverse micelles. Biotechnol Prog 2005;21(4):1192-1197.

14. Morikawa Y, Karube I, Suzuki S. NAD recycling in the collagen membrane. Biochim Biophys Acta 1978;523(1):263267.

15. Barstow DA, Clarke AR, Chia WN, Wigley D, Sharman AF, Holbrook JJ, Atkinson T, Minton NP. Cloning, expression and complete nucleotide sequence of the Bacillus stearothermophilus L-lactate dehydrogenase gene. Gene 1986;46(1):47-55.

16. Blachnitzky EO, Wengenmayer F, Kurz G. D-Galactose dehydrogenase from Pseudomonas fluorescens. Purification, properties and structure. Eur J Biochem 1974;47(2):235-250.

17. Ruther U, Koenen M, Otto K, Muller-Hill B. pUR222, a vector for cloning and rapid chemical sequencing of DNA. Nucleic Acids Res 1981;9(16):4087-4098.

18. Carlsson H, Prachayasittikul V, Bülow L. Zinc ions bound to chimeric His4/lactate dehydrogenase facilitate decarboxylation of oxaloacetate. Protein Eng 1993;6(8):907911.

19. Buckel P, Zehelein E. Expression of Pseudomonas fluorescens Dgalactose dehydrogenase in E. coli. Gene 1981;16(1-3):149-159.

20. Bradford MM. A rapid and sensitive method for the quantitation of microgram quantities of protein utilizing the principle of protein-dye binding. Anal Biochem 1976;72:248254.

21. Laemmli UK. Cleavage of structural proteins during the assembly of the head of bacteriophage T4. Nature 1970;227(5259):680-685.

22. Noll F. L-(+)-Lactate. In: Bergmeyer HU, ed. Methods of Enzymatic Analysis, 3rd ed. Deerfield Beach/Florida, Basel: Verlag Chemie Weinheim. 1984: 582-588.

23. Lindbladh C, Rault M, Hagglund C, Small WC, Mosbach K, Bülow L, Evans C, Srere PA. Preparation and kinetic characterization of a fusion protein of yeast mitochondrial citrate synthase and malate dehydrogenase. Biochemistry 1994;33(39):11692-11698.

24. Elcock AH, McCammon JA. Evidence for electrostatic channeling in a fusion protein of malate dehydrogenase and citrate synthase. Biochemistry 1996;35(39):12652-12658.

25. Elcock AH, Potter MJ, Matthews DA, Knighton DR, McCammon JA. Electrostatic channeling in the bifunctional enzyme dihydrofolate reductase-thymidylate synthase. J Mol Biol 1996;262(3):370-374.

26. Srivastava DK, Bernhard SA. Mechanism of transfer of reduced nicotinamide adenine dinucleotide among dehydrogenases. Biochemistry 1985;24(3):623-628.

27. Srivastava DK, Bernhard SA, Langridge R, McClarin JA. Molecular basis for the transfer of nicotinamide adenine dinucleotide among dehydrogenases. Biochemistry 1985;24(3):629-635.

28. Carlsson H, Ljung S, Bülow L. Physical and kinetic effects on induction of various linker regions in betagalactosidase/galactose dehydrogenase fusion enzymes. Biochim Biophys Acta 1996;1293(1):154-160.

29. Teschke CM, King J. Folding and assembly of oligomeric proteins in Escherichia coli. Curr Opin Biotechnol 1992;3(5):468473.

30. Van Dyk TK, Gatenby AA, LaRossa RA. Demonstration by genetic suppression of interaction of GroE products with many proteins. Nature 1989;342(6248):451-453.

31. Bülow L, Mosbach K. Multienzyme systems obtained by gene fusion. Trends Biotechnol 1991;9(7):226-231. 